Petri Jokinen

FM, taiteen tutkija

\title{
Ajan ja tilan merkkejä Chris Markerin elokuvassa La Jetée
}

Tämä teksti pohtii sitä, miten jokin taideteos - tässä tapauksessa elokuva - voi toimia vertauskuvallisena esityksenä jostakin historiallisesta aikakaudesta. Tämän lisäksi se pyrkii ottamaan kantaa poliittisen tulkinnan mahdollisuuteen ylipäätään. Se esittää ratkaisuksi historiallista tulkintatapaa analyyttisen tulkintatavan sijasta, käyttäen Chris Markerin elokuvaa La Jetée (La Jetée, Ranska 1962) esimerkkiteoksenaan. Tässä tulkinnassa teos toimii allegoriana nykyisestä aikakokemuksestamme omassa postmodernissa nykyhetkessämme. Elokuva näyttäytyy lopulta luonteeltaan paradigmaattisena, sillä se on yhtenä ensimmäisistä teoksista kuvannut postmoderniin aikaan liittyvää ajan ja tilan problematiikkaa. Myös todellisuuden kuvallinen luonne on keskeisessä osassa pyrkiessämme määrittelemään omaa aikaamme historiallisesti. Kuitenkin erilaiset epähistoriallistavat tulkintatavat ovat olleet hyvin yleisiä akateemisen tutkimuksen piirissä; niitä yhdistää tietynlainen metodologinen abstrahointi, joka kaventaa tutkimuksellisen problematiikan jonkin tieteenalan sisäiseksi analytiikaksi ja jättää laajemman historiallisen horisontin huomiotta. Juuri tätä lähestymistapaa tekstissä pyritään vastustamaan. La Jetéen tulkinta on tarkoitettu demonstraatioksi historiallistavan tulkintatavan mahdollisuuksista; se on luonnollisesti vain yksi näkemys tähän aihepiiriin, yksi siitä esitetty tulkinta muiden mahdollisten tulkintojen joukossa. Teksti rakentuu siten, että ensin on abstrakti johdanto, jota seuraa varsinainen käsittelyosuus. Johdanto esittelee käsiteltäviä teemoja, mutta ei mene niihin vielä sen tarkemmin. Teksti on tarkoitettu luonteeltaan pohdiskelevaksi; sen ei ole tarkoitus tarjota jotakin lopullista vastausta siinä käsiteltyyn tulkinnan ongelmaan.

Jotta ajassa matkustaminen olisi mahdollista, tulee olla jokin kiinnekohta, johon ihmismieli voi kiinnittyä, jotain inhimillisesti merkityksellistä. Chris Markerin elokuvassa La Jetée tämä kiinnekohta on kaukainen muisto, hämäryyden peitossa oleva hetki, joka vähitellen paljastaa olemuksensa. Ajan moneus on tässä teoksessa suljettu, sillä matkustajan aloittaessa matkansa aika on jo pysähtynyt; se on jähmettynyt struktuuriksi, jota ilmentää elokuvan koostuminen erillisistä still-kuvista. Siinä ilmenee historian loputon ulkoisuus tai vieraus subjektiin nähden - sen radikaali "toiseus". Nämä hetket ovat vailla temporaalista ulottuvuutta, ja niitä määrittää immanenssin sijasta etäisyys; ne pakenevat ymmärrystä ajan jähmettyessä omaan kristallisoituneeseen liikkumattomuuteensa. Omasta postmodernista nykyhetkestämme puuttuva ajallisuuden kokemus - siten kuin esimerkiksi Fredric Jameson (1991, 18-31) sen ymmärtää - ilmenee tässä elokuvassa tilallisena rakenteena, joka 
toimii sen päähenkilölle loputtoman kontemplaation kohteena. Samalla tavoin meillä ei ole nykyhetkessä sitä utooppista kykyä kuvitella tulevaisuutta, joka vielä hallitsi niin suvereenisti modernia aikakautta, vaan uppoudumme sen sijaan menneisyyteen nostalgisen kaipuun kautta (Jameson 1991, 19-21), kuten La Jetéen ajasta irrallaan oleva päähenkilö.

Kuva 1. Näkökentän peittävät silmälaput. Kuvakaappaus elokuvasta $L a$ Jetée.

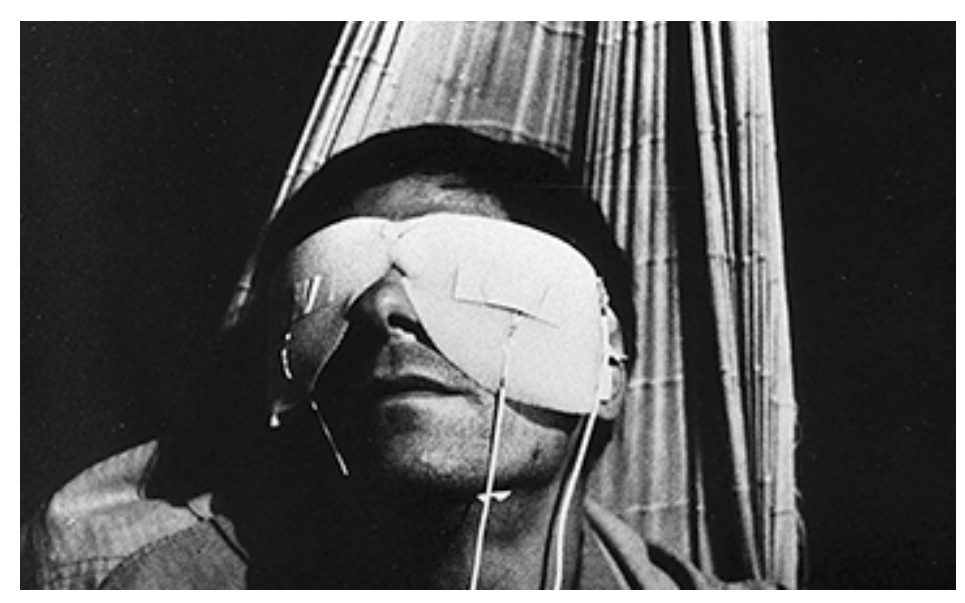

Kuva 2. Yhteys maailmaan kuvien kautta. Kuvakaappaus elokuvasta La Jetée.

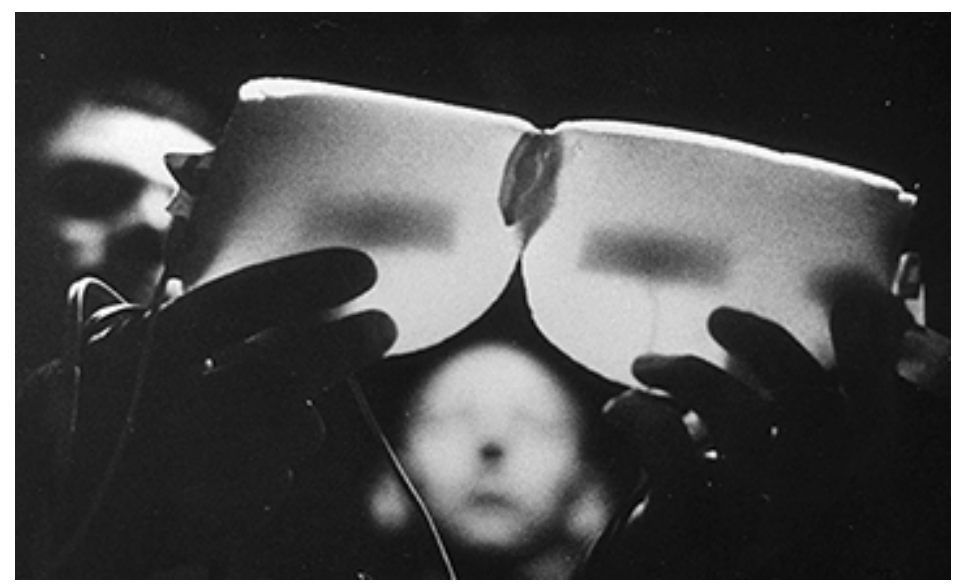

On merkityksellistä, miten tässä elokuvassa historiallisena referenttinä toimii juuri kuva, joka on tietty pysähtynyt menneisyyden hetki. Kuvalla itsellään on identiteetti, ja me tunnistamme siinä näin itsemme. Hetket historiassa ilmenevät meille juuri representaatioiden, kuvien muodossa; emme pääse suoraan käsiksi historiaan, vaan tarvitsemme tähän tarkoitukseen jonkinlaisen välittäjän tai välikappaleen - kuten ajassa matkaaja tarvitsee muiston. La Jetéessä tämä nostalginen viittauskohde on päähenkilön kuoleman todistava nainen, joka on läsnä kaukaisen ja tavoittamattoman muiston muodossa. Mutta onko tämä muisto "järjestetty" - eli onko tämä kokemus muovattu jo ennalta nykyisyyden vallanpitäjien toimesta? Emme tule koskaan tietämään vastausta, mutta "historian agentit" olivat kuitenkin valmiina odottamassa; he tiesivät odottaa päähenkilöä tässä tietyssä menneisyydessä, tässä tietyssä ajassa, joka aktualisoituu paradoksaalisesti juuri tuossa hämäryyden peitossa olevassa muistossa vasta silloin, kun päähenkilö lopulta kokee sen. Nostalgisen kaipuun kautta ilmenevä historia kiehtoo meitä samalla tapaa kuin tämä hetki kiehtoo tuota miestä. Nostalginen paluu ei kuitenkaan vapauta historiaa, vaan vangitsee meidät sen sisään; se ei tarjoa mahdollisuutta nähdä omaa nykyisyyttämme radikaalilla 
tavalla, kuten Walter Benjamin (1989, 186-189) esitti utooppisella voimalla ladatun nyt-hetken (jetzzeit) salatun potentiaalin, vaan tarjoaa meille ainoastaan näennäisen ja hetkellisen tavan paeta omaa nykyisyyttämme.

Prisma hajottaa valon lukemattomiksi aallonpituuksikseen - samoin tämä elokuva hajottaa ajan niiksi kolmeksi ulottuvuudeksi, jotka meidän kokemuksemme siitä sisältää: menneisyydeksi, nykyisyydeksi ja tulevaisuudeksi. Näkeminen ei kuitenkaan tarjoa siinä ulospääsyä, vaan ainoastaan esittää meille ajan olemuksen sinällään, abstraktina mahdollisuutena. Sen tyhjänä referenttinä toimii nykyhetki, joka on vain oman itsensä merkityksetön peili tai kahdentuma. On merkityksellistä, miten tieteisfiktion ensimmäisessä aikamatkustustarinassa, H. G. Wellsin vuoden 1895 romaanissa Aikakone (The Time Machine) ${ }^{1}$, vain tulevaisuus, joka on ehkä joskus syntyvä, on merkityksellinen. ${ }^{2}$ Teoksen päähenkilöä kiehtoo nimenomaan idea tulevaisuudesta; se, mitä se tuo lopulta tullessaan - mutta myös tuo tulevaisuus itse kätkeytyy siinä loputtomiin varjoihin; tiedon tummaan aineeseen. Omassa nykyhetkessämme menneisyys näyttäytyy meille huomattavasti mielenkiintoisempana kuin tulevaisuus: me katsomme oman aikamme epävarman nykyisyyden lävitse menneisyyteen, sillä vain sieltä voimme löytää kadottamamme identiteetin, todellisen yhteyden maailman ja itsemme välillä.

Myöhäiskapitalismin luoma radikaali epäjatkuvuus ja epävarmuus sekä ajassa että tilassa on mitä ilmeisimmin aiheuttanut tämän nostalgisen kaipuun, samoin kuin se on myös kaventanut aikaperspektiivimme ainoastaan tähän loputtomaan nykyhetkeen. Historian se on korvannut sen jäljitelmällä eli kuvalla (Jameson 1991, 18-21). Kulutusobjektit - erityisesti niin sanotut kulttuurintuotteet - pyrkivät kuitenkin paradoksaalisesti tarjoamaan meille tavan sovittaa tämä Olemisen ristiriita. Tässä esiin tuleva argumentti ilmeni hieman eri muodossa Martin Heideggerin ja Georg Lukácsin moderneissa filosofioissa - nykyisin kuitenkin erona on se, ettei tällaista subjektin ja objektin mahdollista yhtenäisyyttä voi olla enää olemassa - ei edes idean tasolla, vaan nyt mahdollista on ainoastaan kuvien kaikkialla läsnä oleva spektaakkeli, johon me jatkuvasti turvaudumme, ja joka siten ilmentää ainoastaan omaa vieraantumistamme tässä postmodernissa ajassa, jossa suhde ilmiöihin ja objekteihin ei ole enää modernin ihmisen vieraantunut suhde, kuten yllä mainituilla ajattelijoilla, vaan sitä määrittää - jokseenkin paradoksaalisesti - uudenlainen affirmaatio juuri ilmiömaailman kokonaisvaltaisen tavaroituneesta luonteesta johtuen. Todellisuus on, Jean Baudrillardin $(1990,9)$ sanoin, hyperreaalinen: todellisempi kuin todellisuus itse.

\section{II}

Minkäänlainen paluu modernin aikakauden keskeisiin ajattelijoihin ei siis voi valaista tässä esiin tulevaa aihepiiriä, sillä ongelmanasettelu on nykyisin tyystin toinen. Modernin ajan teoriat sopivat yleensäkin sangen huonosti kuvaamaan kaikkialla läsnä olevan "maailmanjärjestelmämme" uusimman vaiheen luoman kulttuurin ominaispiirteitä. Voimme tässä artikuloida ongelman suoraan: tämä kritiikki oli vielä taaksepäin katsovaa, jollakin tapaa konservatiivista, jonkinlaiseen olemukselliseen

1 Katso Wells 2017 (tai vaihtoehtoisesti jokin muu painos).

2 Mielenkiintoisesti tämä pätee myös tieteiselokuviin: ennen 1960-lukua (ja osittain myös sen aikana) ilmestyneet teokset katsoivat vielä tulevaisuuteen menneisyyden sijasta. Niissä esiintyivät kaikenlaiset uudet teknologiat ja historian ennakoimattomat käänteet odottivat inmistä toteutuakseen. Nyt tämän tulevaisuuden kuvittelun on ottanut haltuunsa dystooppinen juonne, joka suhtautuu siihen kategorisen kielteisesti. 
eheyteen uskovaa (myös vasemmistolaisilla ajattelijoilla, kuten esimerkiksi Adornolla - vaikka hän olisi itse tämän varmasti jyrkästi kiistänyt). Heidän tulkinnallinen perspektiivinsä määrittyi suuressa määrin sen kautta, mitä oli ollut olemassa aiemmin nimenomaan porvarillisen kulttuurin piirissä. Näin jäljelle jäi lopulta ainoastaan mahdoton kieltäytymisen ja abstinenssin asenne. Tämä negatiivisuus ei kuitenkaan edustanut todellista modernia dialektiikkaa, vaan käänsi selkänsä tuolloin edelleen muotoutumassa olevalle modernille maailmalle: siitä ei johtanut ulos mitään uutta luovaa reittiä, ja näin ollen sen täytyi välttämättä kääntyä kohti menneisyyttä. Heideggerilla ja Nietzschellä - oikeastaan heidän koko tuotannossaan - tämä oli filosofisen diskurssin sisällä abstrahoitu epäpaikka: filosofia ennen filosofiaa alkuperäisen fenomenaalisen ykseyden maailmassa; filosofia myytin ja rationaalisuuden rajalla. Marxilaisessa teoriassa haluttomuus osallistua kapitalistisen järjestelmän luomaan kulttuuriin johti samalla tapaa ajattelun tasolla erikoiseen asketismiin, jonka utooppinen ideaali artikuloitui sellaisessa mahdottomassa luomisessa, joka operoi tämän maailman tuolla puolen kaiken käsitteellisen ajattelun ulottumattomissa. Näin sen mahdollisuus oli samalla tapaa suljettu kuin edellä mainituilla konservatiivisilla ajattelijoilla. ${ }^{3}$ Molemmissa tapauksissa todellinen historia oli sulkeistettu; abstrahoitu pois jonnekin ajattelun horisontin tuolle puolen.

La Jetée voidaan helposti tulkita eräänlaisena oppituntina "nykyisyyden ontologiasta"; yrityksenä tavoittaa nykyhetken historiallinen erityisolemus. Sen pakottavuus nimenomaan nykyhetkessä tuntuu ilmeiseltä - mutta pohtiessamme tämän filosofisen tulkintaoperaation mahdollisuutta, meidän tulee samalla muistaa, että analyysi on luonteeltaan aina myös ideologista, siinä missä se on fenomenologista. Ja näin ollen, kohdistui tämä tulkitseva katse mihin tahansa spesifiin aikakauteen - omassa tapauksessamme myöhäiskapitalistiseen järjestelmään tai postmoderniin aikaan - tulee sen olla luonteeltaan aidosti historiallista. Se, mitä tämän tutkimusotteen täytyy näin ollen välttää, on kaikenlainen epähistoriallistava ote, joka jakaa kokemuksen oman erityistietämyksen analyyttisiksi kategorioikseen, kuin jotakin olentoa pöydällään osiksi leikkelevä tutkija. Tämä on tieteellisen tutkimuksen vaara ylipäätään, sillä moderni analyyttinen järki operoi juuri tällä tapaa. ${ }^{4}$ Tämä kaiken neutralisoiva ote on vältettävissä ainoastaan siten, että tutkija pitää näköpiirissään sen laajemman totaliteetin, joka on alun perin aiheuttanut näiden osa-objektien olemassaolon. Nykyisin, kuten esimerkiksi Lyotard $(1984,4)$ on esittänyt, toisistaan eriytyneet tieteenalueet ovat myös elimellisesti suoraan yhteydessä kapitalistisen järjestelmän luomaan markkinalogiikkaan - sekä ovat myös toisiinsa nähden tyystin yhteismitattomia. Tämä periaate itsessään luo tieteenalojen sisälle omia muotejaan, jotka sitten vielä asettavat tiettyjä tulkinnallisia rajoituksia sekä temporaalisessa että spatiaalisessa mielessä. ${ }^{5}$

Myöskään minkäänlainen yleinen kulttuurikritiikki, jota Bauman $(1992,45)$ kutsuu kulttuuri-ja-persoonallisuus-kouluksi, ei tule kyseeseen, sillä sen näkökulma

\footnotetext{
3 Adornon Esteettinen teoria (Ästhetische Theorie, 1970) on tämän ajatuslinjan lopullinen kiteytymä. Katso Adorno 2006.

4 Tämä analyyttinen metodi voidaan palauttaa aina Descartesin filosofiaan saakka.

5 Yksi selkeä syy, joka mielestäni estää nykyhetkessä tällaisen laajemman historiallisen tulkintayrityksen ovat ennen kaikkea erilaiset "toiseuden politiikat", jotka jo lähtökohtaisesti vastustavat kaikkea tällaista totalisoivaa ajattelua. Tässä yhteydessä minkäänlainen vakavampi kritiikki ei tule kuitenkaan kyseeseen (tilan ollessa hyvin rajoitettu), mutta totean silti lyhyesti niiden äärimmäisen kaventavasta tulkinnallisesta horisontista, joka korvaa todellisen poliittisuuden konstruoitujen pseudo-ongelmien poliittisuudella. Siinä myös itse teoriaa tarjotaan ratkaisuksi käytännön ongelmille, ja pyritään näin suorittamaan jonkinlainen uskonhyppy, jossa vastustava "luenta" hävittää sen itsensä luoman ongelman jonkin taikaloitsun tavoin.
} 
palautuu yleensä pinnalliseen "aikalaisanalyysiin", joka pyrkii konstruoimaan asioille ja ilmiöille oman "maailmanselityksensä", ollen täten yksi esineellistyneen kulutusyhteiskunnan osa sen oman itseymmärryksen vapaalla markkinapaikalla. Se kieltäytyy kategorisesti laajentamasta analyysiään millekään sitä syvemmälle systeemiselle tasolle, ja näin sen yksilötason vastineena voidaan tietyssä mielessä nähdä kaikki populaarit elämäntapaoppaat, joiden aluetta on postmoderni "itsen kulttuuri". Kaikki tällaiset analyysiyritykset ovat kyllä päteviä jossakin rajoitetussa mielessä, mutta ne tematisoivat samalla sellaisia radikaalisti esineellistyneitä piirteitä, joiden syvällisempi selitys löytyy aina huomattavasti monimutkaisemmasta yhteiskunnallisesta totaliteetista. Ne myös vaativat funktionaalisen tulkinnan tullakseen ymmärrettäväksi varsinaisesti ideologisesta näkökulmasta, joka sitten vasta avaa meille näkymän näitä ilmiöitä huomattavasti laajempiin historiallisiin rakenteisiin, joiden viimekätinen logiikka palautuu maailmanjärjestelmämme materiaaliseen erityisolemukseen.

Postmoderni aikakausi, postmodernismi, postmoderniteetti - nämä yhteenkokoavat käsitteet voivat tuntua joistakin nyt jo hieman vanhentuneilta, ja niitä on seurannut muutamia uusia käsitteitä, jotka omasta mielestäni ovat usein tarpeettomia, ja pahimmillaan jopa haitallisia, sillä ne hämärtävät sitä laajempaa ymmärrystä, jonka edellä mainitut käsitteet ovat meille omasta historiallisesta tilanteestamme tarjonneet. Tarkoitan tässä kaikenlaisia uusia post-käsitteitä, ${ }^{6}$ joista ehkä kaikkein paradoksaalisin on itse post-postmodernismi. Tämä mahdoton sanahirviö ei ole ongelma sinänsä - eikä sitä tule mielestäni millään tavoin yksilöidä lukuisten sitä muistuttavien käsitteiden joukosta - vaan ongelmallista ovat siihen sisältyvät lukuisat implikaatiot, joista keskeisin on se, että kyseessä olisi jo alun perin ollut vain jokin nopeasti ohimenevä tyylisuunta tai muoti, joka korvautuu vääjäämättä jollakin toisella (ja näin ollen itse postmodernismi kuuluisi eräiden kommentoijien mukaan nyt jo historiaan jonkinlaisena lyhytikäisenä periodityylinä). Jos sen sijaan ymmärrämme postmodernismin "myöhäiskapitalismin kulttuurillisena logiikkana", kuten Fredric Jameson (1991) asian kuuluisasti aikanaan ilmaisi, emme edelleenkään tarvitse mitään tällaisia jokseenkin epätoivoiselta kuulostavia kielellisiä konstruktioita kuvaamaan nykyhetkemme erityisolemusta.

Fredric Jamesonin postmodernismin teoriassa vallankumouksellista oli juuri sen historiallinen - tai ehkäpä vielä tarkemmin ilmaistuna sen historiallistava - luonne. Hän pyrki osoittamaan, miten materiaaliset muutokset itse tuotantovälineissä ovat johtaneet modernin aikakauden periaatteiden ja arvojen katoamiseen, ja uudenlaisen kulttuurillisen periaatteen (sekä kokemusmaailman) nousuun osana tätä myöhäiskapitalistista maailmaa. Omassa teoriassaan hän on nojautunut vahvasti marxilaisen taloustieteilijä Ernest Mandelin (1976) teoriaan myöhäiskapitalismista (Late Capitalism -teos ilmestyi alun perin vuonna 1972). Näin ollen, jos siis toteamme, että tämä materiaalinen perusta ei ole ratkaisevasti muuttunut näinä kuluneina vuosikymmeninä, vaan että se on sen sijaan pikemminkin kehittynyt pitemmälle - tai radikalisoitunut, jos tämä ilmaisu tässä yhteydessä sallitaan - voimme todeta nämä post-post-ratkaisut jokseenkin turhiksi ja harhaanjohtaviksi. Elämme edelleen postmodernia aikaa, joka on itse asiassa vasta aluillaan ja kehittymässä kohti omaa "täydellistymistään". Meidän tulisikin nyt mielestäni syventyä uusien postkäsitteiden sijasta tämän aikakauden tarkempaan historialliseen analyysiin, sillä on tullut mielestäni selväksi, ettei sille ominainen esteettinen muodontuotanto ole

6 Näiden termien täsmällinen nimeäminen ei ole mielestäni merkityksellistä, sillä ne kaikki ovat jollakin parasiittimaisella tavalla yhteydessä itse postmodernismin käsitteeseen, mutta pyrkivät (epäonnistuneesti) ylittämään sen. Ne ovat merkki aikamme kärsimättömästä luonteesta ja tarpeesta luoda loputtomiin uusia muotikäsitteitä akateemisen tutkimuksen globaalille markkinapaikalle. 
missään tapauksessa pysähtynyt, ja että sitä määrittävät kapitalismin nykyvaiheen historialliseen erityisluonteeseen liittyvät seikat, joiden tarkempi analyysi voi vasta paljastaa asioiden ja ilmiöiden todellisen olemuksen.

Kuva 3. Menneisyys. Aika. Viittaus Hitchcockin Verti-goon. Kuvakaappaus elokuvasta La Jetée.

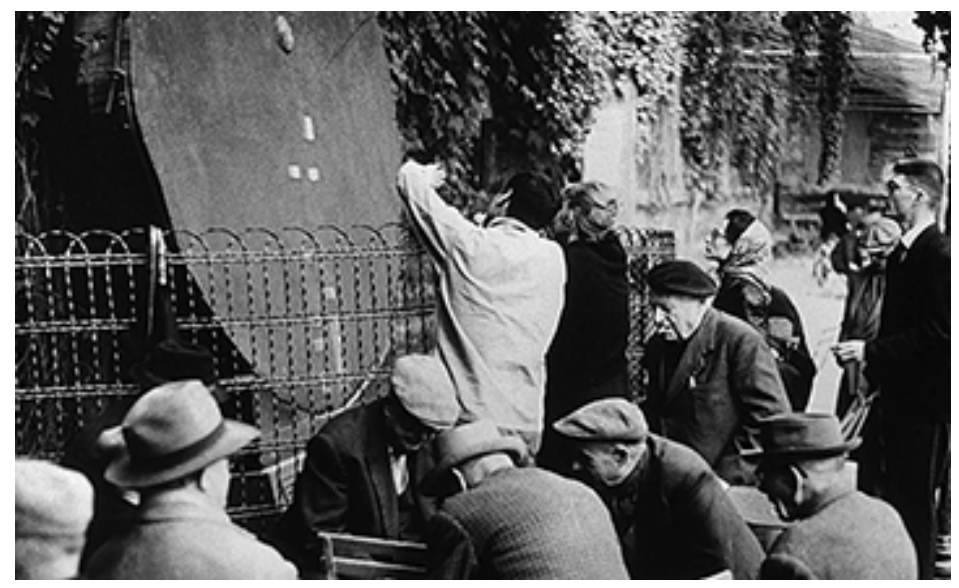

Vaihtakaamme nyt jälleen hieman näkökulmaa. Yllä olevan yleiskatsauksen jälkeen on aika palata kokevaan subjektiin, jonka jätimme edellä taaksemme - vaikka täytyy silti todeta, että subjekti ilmenee tässä yhteydessä pikemminkin kokemuksellisena struktuurina kuin minään sitä laajempana modernina versiona, joka antaisi sille jonkin olemuksellisen eheyden. Näemme Chris Markerin elokuvassa La Jetée, miten aikamatkaaja on ruumiillisesti passiivisessa tilassa: hänen silmilleen on asetettu näkökentän peittävät laput, ja hänen ainoa keinonsa matkustaa ajassa on kuvitella se; lyhyesti ilmaistuna hän näkee siitä kuvia. Tämä vastaa täydellisesti omaa tilannettamme nykyajassa, jossa olemme samalla tapaa sidottuja liikkumattomuuteen, mutta olemme silti kokemuksellisesti yhteydessä maailmaan kuvien, erilaisten representaatioiden kautta: ne ovat meille nykyisin itse maailma kaikessa rikkaudessaan. Huomionarvoista on kuitenkin se, että tämä toiminta on täysin passiivista: me vastaanotamme kuvia; se on itse asiassa meidän ensisijainen funktiomme subjekteina. Nykyisin kuvatuotanto on jossakin määrin demokratisoitunut, mutta tämä ei silti ole poistanut kuvien kulutusluonnetta: tarvitaan edelleen katsojia ja vastaanottajia, ja huomionarvoisesti suuri osa yleisöstä kuuluu edelleen tähän joukkoon. Vaikka myöhempi kulttuurintutkimus ${ }^{7}$ on siirtänyt huomiotaan modernin ajan ongelmanasettelusta audiovisuaalisten tekstien "lukemiseen", pätevät mielestäni monet aiemmista mediaa koskevista teoretisoinneista edelleen. Näin ollen kuluttajan aktiivista roolia korostavat tulkintalinjat ovat mielestäni usein harkitun yksipuolisia ja taktisen vääristeleviä.

Fenomenaalinen saa ideologisen selityksensä laajemmista yhteiskunnallishistoriallisista suhteista: kuvallisuus on oman olemassaolomme perusta osana sitä "spektaakkelin yhteiskuntaa", joka Guy Debordin (1995) mukaan edustaa asioiden yleistä tilaa nykyhetkessä. Hänen mukaansa kuvalliset representaatiot ovat nykyisin korvanneet ilmiöiden välittömän kokemuksen: meille kuva itse ON maailma ja olemisemme perusta. Näin olemme ikään kuin "vangittuja näkemään", kuten La Jetée -elokuvan päähenkilö. Hän kuitenkin kokee tämän näkemisen, eli ajassa matkustamisen, vapautumisena - aivan samalla tapaa kuin me koemme kuvallisen kulttuurin omassa nykyhetkessämme vapautumisena ajan ja tilan kahleista. Näkemisemme on

7 Klassinen teos tässä yhteydessä on John Fisken vuoden 1987 Television Culture. 
näin ollen samalla tapaa esineellistynyt (Lukács 1971, 83-109) kuin tämän elokuvan päähenkilöllä. Näkemisellä ja visuaalisuudella on tunnetusti tätä huomattavasti laajempi historia, mutta tässä yhteydessä ei ole mielestäni tarpeen konstruoida mitään erityistä "kuvan arkeologiaa", sillä merkityksellistä on mielestäni tämä asiantila juuri eksistentiaalisena seikkana eli osana nykyisiä kulutusyhteiskunnan käytäntöjä. Näin ollen mikään historiakatsaus ilmiön itsensä menneisyyteen ei pysty valaisemaan asiaa sen paremmin, vaan ehkä pikemminkin ohjaa huomiotamme toisarvoisiin seikkoihin suoremman poliittisen tulkinnan sijaan.

On silti tärkeätä muistuttaa kaiken sanotun jälkeen siitä, että analyysimme kohteena on lopulta taideteos, joka on syntynyt 1960-luvun alussa eli aivan oman aikamme aamuhämärissä. ${ }^{8}$ Se ei voi näin ollen antaa vastauksia kaikkiin nykyhetkeä koskeviin kysymyksiin, mutta tästä huolimatta se voi auttaa ymmärtämään aikamme luonnetta sen kaikkein yleisimmällä tasolla. Tämä teos välittää meille tietyn kuvallisuuteen liittyvän kokemuksen, joka on meille kaikille tuttu elettyämme osana tätä maailmaa: kokemuksen, joka liittyy lopulta aikaan ja sen erityisolemukseen. Perustavanlaatuisten havainnointia strukturoivien seikkojen - sekä ajan että tilan - muutos olemassaolomme materiaalisen perustan kokeman muutoksen aiheuttamana on tekstini keskiössä, samalla tapaa kuin aiemmin käsitelty kuvallisuuden tematiikkakin. Analysoin niiden merkitystä tarkemmin alla ottaen siinä La Jetéen eräänlaiseksi paradigmaatiseksi esimerkiksi nykyajan historiallisesta ominaisluonteesta.

\section{III}

Aikamatkustuksen idea ${ }^{9}$ syntyi modernilla aikakaudella, mutta siitä on tullut keskeinen oikeastaan vasta omalla ajallamme. Näemme, miten kyse ei ole enää ajasta sinänsä - niin kuin oli asian laita vielä modernististen teosten muotokokeiluissa tai tieteiskertomusten optimistisissa tulevaisuuskuvitelmissa - vaan sen sijaan kyse on tilasta: useissa nykyajan aikamatkustusta kuvaavissa narratiiveissa menneisyys on nimenomaisesti paikka, jossa vierailla. Sillä on yleensä nostalgisia konnotaatioita - eli se on niissä jonkinlaisen kollektiivisen kaipuun kadotettu kohde. Näin on esimerkiksi Robert Zemeckisin Paluu tulevaisuuteen -elokuvasarjassa (Back to the Future I-III, USA 1985-1990). ${ }^{10}$ Sen referenttinä toimii Amerikan kadotettu kulta-aika eli Eisenhowerin ajan 1950-luku kaikkine siihen liittyvine esteettisine fetissiobjekteineen (sekä Marxin että Freudin tarkoittamassa mielessä) aina vaatetuksesta ja hiustyyleistä automalleihin ja pop-kappaleisiin. Huomionarvoista on se, että tämä aikakausi herää eloon nimenomaan kulutustuotteiden uudelleen kuvittelun kautta - seikka, joka vahvistaa tässä tekstissä esitettyä näkemystä postmodernin kulttuurin kuvallisesta erityisluonteesta. ${ }^{11}$ Tämä nostalgisen kokemuksen keskittyminen kulutusobjekteihin johtuu myös osaksi siitä, että omassa kulttuurissamme arkinen on myös kaikkein katoavaisinta: kulutus arkisena periaatteena johtaa siihen, että esineiden ja asioiden käyttöikä on hyvin lyhyt. Kuitenkin näille esineille annettu

8 Fredric Jameson on määritellyt postmodernia aikakautta siten, että eräänlainen paradigman siirtymä tapahtuu Yhdysvalloissa 1950-luvun kuluessa ja muissa keskeisissä länsimaissa 1960-luvun kuluessa. Tällöin modernismi alkaa korvautua postmodernismilla moninaisten historiallisten muutosten ansiosta. Katso Jameson 1991, 1.

9 Tai jos ollaan tarkkoja: nimenomaan idea aikamatkustuksesta, jonkin siihen tarkoitukseen valmistetun koneen avulla.

10 Joka toteuttaa omaa versiotaan Nietzschen "ikuisen paluun myytistä" alati toistuvine tilanteineen. 11 Lienee hieman turhaa lisätä, että kyseessä on todellakin ainoastaan kuva, ei todellinen historiallinen aikakausi vaan esteettinen konstruktio: menneisyys idealisoituna objektina. 
arvo (eli vaihtoarvo, kuten Marx [1974, 56-77] asian ilmaisi) sinänsä on suuri; tästä syntyy se sovittamaton ristiriita, josta nostalginen kaipuu lopulta syntyy, ja johon se tarjoaa oman hetkellisen pseudo-ratkaisunsa. Lopulta tärkeintä on kuitenkin se, että aika itse ikään kuin esineellistyy näissä teoksissa ja ilmenee meille tilallisten representaatioiden kautta välittömästi tunnistettavana esteettisenä joukkona tai kasaumana (katso tästä aiheesta laajemmin Jameson 1991, 16-25).

Ehkä kaiken edellä sanotun jälkeen herää oikeutettu kysymys siitä, miten aiemmin esitetty yleinen keskustelu "teoriasta" liittyy tässä tarkemmin ottaen itse teoksen analyysiin. Vastaus liittyy ennen kaikkea historiallisuuteen ja siihen, miten nämä molemmat luovat jonkin käsityksen nykyhetkestä. Tiede, joka pystyy problematisoimaan oman luonteensa ja näkemään omat rajoituksensa omassa toteutumisessaan radikaalisti nykyhetkisenä, ja samalla tavoin taideteos, joka antaa meille oppitunnin siitä, miten emme voi nykyisin paeta tätä nykyhetkisyyttä tai nykyisyyttä, sillä se tavoittaa meidät varmasti, kuten historian agentit elokuvan päähenkilön. Tämä on lopulta myös poliittinen huomio, sillä se liittyy niihin materiaalisiin ehtoihin, joiden puitteissa me nykyajassa elämme. Ideologisella tasolla vain nykyhetkellä on merkitystä tämän järjestelmän kannalta; näin voimme lopulta esittää ehkä jossain määrin radikaalilta tuntuvan väitteen: nykyisyys ja siihen liittyvä taide ilmentää nimenomaan tätä asiantilaa eli sitä, että nykyisyys on puhdasta nykyisyyttä vailla menneisyyttä ja tulevaisuutta. Tekstissä käsitellyssä teoksessa nykyinen asioiden tila ilmenee sekä muodon että sisällön tasolla; tässä suhteessa se on esimerkillinen teos pyrittäessä tulkitsemaan taidetta allegorisesti juuri historiallisen aikakauden edustajana.

Kuva 4. Tulevaisuuden vieraus. Kuvakaappaus elokuvasta La Jetée.

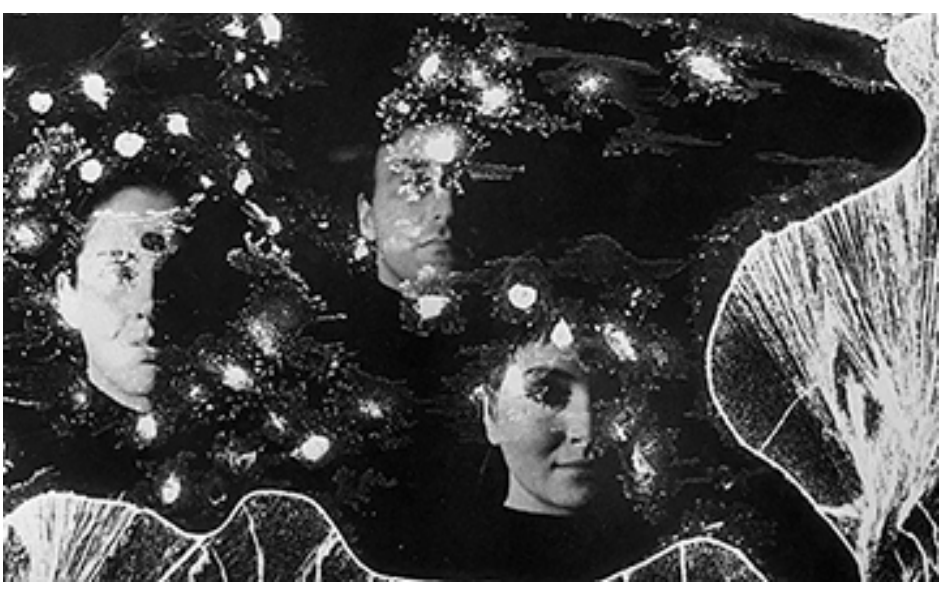

Kuva 5. Päähenkilön kuoleman todistava nainen. Kuva:kaappaus elokuvasta La Jetée.

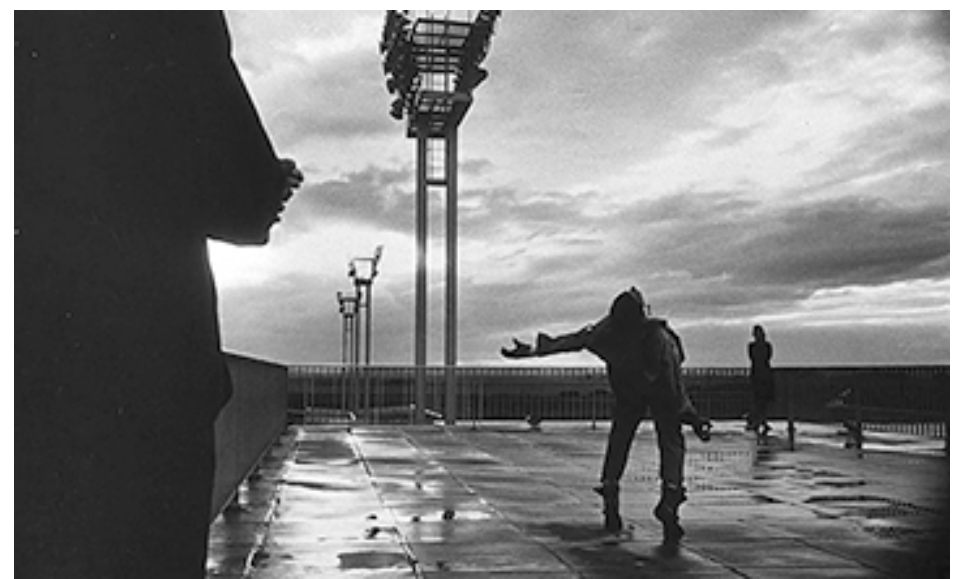


Tässä esitettävä näkökulma eroaa näin ollen niistä radikaalin eron filosofioista, joita Ranskassa viime vuosisadan loppupuolella kehittyi. Se olettaa sen sijaan jonkin (materiaalisen) totaliteetin, jota vasten taidetta ja kulttuuria täytyy tarkastella. Ehkä tässä yhteydessä voidaan esittää myös se jokseenkin uskalias ehdotus siitä, että nämä "eron filosofiat" kuuluivat vielä edelleen moderniin aikakauteen; että ne olivat tietyn nimenomaan modernistisen estetiikan inspiroimia vastauksia modernin ajan rationaalisuuden oletetun "totaaliseen" luonteeseen filosofisen diskurssin alueella, ja että meidän tulee täten omassa postmodernissa nykyhetkessämme kategorisesti hylätä nämä kriittiset operaatiot omaan aikaamme sopimattomina. Esimerkiksi Michel Foucault ei koskaan päästänyt irti siitä Toiseuden ajatuksesta, joka hänen ajatteluunsa alusta alkaen sisältyi. Hänen "utopiansa" (ilmaus on tässä yhteydessä ironinen) oli luoda jotakin radikaalisti ulkoista länsimaiseen rationaaliseen diskurssiin nähden; näin hän konstruoi jatkuvasti filosofiansa tämän identifikaatiota pakenevan periaatteen ympärille (seuraten siinä ennen kaikkea Nietzscheä). Hänen viimeisinä vuosinaan kehittelemänsä "olemassaolon estetiikka" esimerkiksi viittasi modernien taiteilijoiden mahdollisuuteen elää jollakin tapaa toisin; luoda elämänsä taideteoksena vastustamaan vallitsevia olemassaolon ehtoja (Foucault 2011, 187-189). Seuraan tässä Andreas Huyssenin (1986, 206-216) näkemystä. Täten jälkistrukturalististen ajattelijoiden, kuten Foucault'n yllä, identifikaatiota ja representaatiota pakeneva ajattelu ei sovellu selittämään oman nykyhetkemme historiallista luonnetta, vaan tämä vaatii sen sijaan marxilaista näkökulmaa, joka pystyy ottamaan huomioon ympärillämme vaikuttavan talousjärjestelmän läpitunkevan vaikutuksen kaikilla inhimillisen toiminnan alueilla - mukaan luettuna, ja erityisesti, taide ja kulttuuri.

Kuten olen todennut, kuva on olemassaolomme historiallinen perusta nykyhetkessä (Debord 1995). Voimme havainnoida, miten se abstraktion periaate, joka representaatioon modernilla aikakaudella sisältyi (vähintäänkin modernismin radikalisoituneessa vaiheessa), ei päde enää nykyisin, vaan että uudenlainen realismi on ilmaantunut sen tilalle. Kuitenkin, jokseenkin paradoksaalisesti, tämän uuden realismin periaatteena on hajaantuneiden ja kierrätettyjen kuvien spektaakkeli, joka ilmenee meille pastissina, erilaisina intertekstuaalisina kerroksina ja simulakrumeina (Jameson 1991, 18-21). Kuva on nykyisin sanan perinteisessä mielessä vailla referenttiä - kuten Jean Baudrillard (1994) on meille opettanut. Tämä kuvan uusi virtuaalisuus (mutta silti aktuaalisine efekteineen) voidaan tulkita myös allegoriaksi fiktiivisen kapitalismin itsensä historiallisesta erityisluonteesta. Mikä tässä on merkittävää, on se nopeus, jolla tätä finanssipääomaa manipuloidaan, sillä myös se itse on olemassa vain representaationa äärimmilleen radikalisoituneessa nykyhetkessä - huolimatta siihen sisältyvistä futuureista, joiden suhteellinen autonomia päättyy pääoman omiin sisäisiin operaatioihin. Tämän finanssipääoman potentiaali sisältyy juuri sen juoksevaan (liquid, Bauman 2000) luonteeseen. Vain ollessaan tässä "nestemäisessä" olotilassa se voi luoda voittoa; olla mitä tahansa eli toisin sanoen ottaa minkä tahansa muodon. Tätä pääomaa ei voi täysin muuttaa joksikin olevaksi, sillä siihen kohdistuvat operaatiot ovat virtuaalisia, ne ovat olemassa ainoastaan representaatioina.

Tulevaisuus on tässä elokuvassa hämärän peitossa; ei siksi, että se olisi sinänsä tavoittamaton, sillä aikamatkaaja pääsee kyllä sinne, vaan siksi, ettei hän ymmärrä sen todellista luonnetta. Hän tuntee itsensä tuohon aikaan kuulumattomaksi vieraaksi. Sen sijaan hän kaipaa takaisin lapsuutensa kadonneeseen maailmaan, tiettyyn hetkeen, joka kiehtoo häntä pakkomielteen tavoin. Nykyisyyden kaventuneesta horisontista tulevaisuus näyttää vieraalta, tavoittamattomalta; se on meille käsittämätön, ja nykyhetken olotila on näin itseensä kiertyvä tautologia vailla ulkoisia määreitä. Tämä nykyhetkisyyden suvereeni hallitsevuus on tämän teoksen viimekätinen opetus. Se kertoo meille siitä olotilasta, johon olemme tässä tietyssä historiallisessa tilanteessa 
tuomittuja. Ainoastaan kuvat tarjoavat meille mahdollisuuden paeta nykyhetkeämme ja tavoittaa jälleen subjektin menetetty identiteetti, mutta huomionarvoisesti myös tämä pako menneisyyteen toteutuu saman kulutusyhteiskunnan puitteissa kuin kaikki muukin. On kuitenkin tärkeää nähdä tämä asioiden tila ja konstruoida jokin fragmentoitunutta ilmiömaailmaa laajempi historiallisesti selittävä totaliteetti, sillä ainoastaan tällainen laajempi tiedostaminen voi johtaa meidät mihinkään aidosti poliittiseen toimintaan (vrt. Jameson 1991, 54).

\section{Lähteet}

Adorno, Theodor (2006/[1970]). Esteettinen teoria. Tampere: Vastapaino.

Baudrillard, Jean (1990/[1983]). Fatal Strategies. New York: Semiotext(e).

Baudrillard, Jean (1994/[1981]). Simulacra and Simulation. Ann Arbor, MI: The University of Michigan Press.

Bauman, Zygmunt (1992). Intimations of Postmodernity. London: Routledge.

Bauman, Zygmunt (2000). Liquid Modernity. Cambridge: Polity Press.

Benjamin, Walter (1989). Messiaanisen sirpaleita. Kirjoituksia kielestä, historiasta ja pelastuksesta. Helsinki: Tutkijaliitto.

Debord, Guy (1995/[1967]). The Society of the Spectacle. New York: Zone Books.

Fiske, John (1987). Television Culture. Studies in Communication. London: Methuen.

Foucault, Michel (2011/[2008]). The Courage of Truth. The Government of Self and Others II. Lectures at the Collège de France 1983-1984. New York: Palgrave Macmillan.

Huyssen, Andreas (1986). After the Great Divide. Modernism, Mass Culture, Postmodernism. Bloomington \& Indianapolis: Indiana University Press.

Jameson, Fredric (1991). Postmodernism, or, the Cultural Logic of Late Capitalism. Durham, NC: The Duke University Press.

Lukács, Georg (1971/[1923]). History and Class Consciousness. Studies in Marxist Dialectics. Cambridge, Mass.: The MIT Press.

Lyotard, Jean-François (1984/[1979]). The Postmodern Condition. Minnesota: University of Minnesota Press.

Mandel, Ernest (1976/[1972]). Late Capitalism. London: New Left Books.

Marx, Karl (1974/[1867]). Pääoma. Kansantaloustieteen arvostelua. 1. osa. Ensimmäinen kirja. Pääoman tuotantoprosessi. Moskova: Edistys.

Wells, H. G. (2017/[1895]). The Time Machine. New York: Macmillan. 